Gut, 1984, 25, 965-970

\title{
Is pentagastrin-stimulated secretion mediated by histamine?
}

\author{
W K MAN, C J H INGOLDBY, AND J SPENCER \\ From the Department of Surgery, Royal Postgraduate Medical School, Hammersmith Hospital, London
}

SUMmary Patients with duodenal ulcer disease received either a two hour pentagastrin infusion test or a similar test with the addition of a bolus of cimetidine, $200 \mathrm{mg}$, after one hour of pentagastrin. Pentagastrin induced secretion of acid and histamine, the secretion patterns of the two being similar. Total histamine output in the gastric aspirate in the first hour of pentagastrin infusion was related to total acid output $(r=0.58, p<0.01)$. A similar correlation was observed during the second hour of pentagastrin infusion $(r=0 \cdot 61, p<0 \cdot 05)$. Plasma histamine concentration rose to a peak coinciding with maximal acid secretion. After cimetidine blockade, gastric acid fell rapidly but gastric histamine output did not change. Plasma histamine concentration increased further. These results suggest that pentagastrin induced gastric histamine release is not affected by an acid inhibiting dose of cimetidine. Cimetidine caused histamine release into the circulation in both healthy volunteers and patients after total gastrectomy. The rise in plasma histamine concentration, however, was transient. In contrast, during pentagastrin infusion, the plasma histamine concentration remained high. These data support the hypothesis that histamine release induced by pentagastrin is a major stimulant of gastric acid secretion.

The mechanism by which the gastric parietal cells are stimulated to produce acid is uncertain. A variety of models have been proposed, with one or more receptor sites on the parietal cell sensitive to different chemical transmitters. ${ }^{1}{ }^{2}$ In many of these models gastrin acts directly on the parietal cell to cause acid release. Gastrin is a potent stimulant of acid secretion, and it has been reported to cause stimulation of metabolic activity in isolated parietal cell preparations. ${ }^{3}$ It is well recognised, however, that there are difficulties in interpretation of isolated cell studies, and evidence of significant parietal cell response to gastrin has not been confirmed.

An alternative view is that gastrin acts indirectly, by releasing a transmitter in the gastric mucosa. One candidate for this role is histamine. We have observed in previous studies that pentagastrin, a synthetic analogue of gastrin, causes release of histamine into the gastric juice and into plasma, with depletion of gastric mucosal histamine stores. ${ }^{4}$ Histamine release is related in time and degree to that of acid, the amount of histamine released correlating with gastric acid secretion. This parallel release is compatible with the hypothesis that

Address for correspondence: Mr J Spencer, FRCS, Department of Surgery. RPMS, Hammersmith Hospital, Du Cane Road. London W12 0HS

Received for publication 2 November 1983 pentagastrin acts indirectly, by causing mucosal histamine release. Histamine may then act on the parietal cell to cause acid secretion.

In order to test this hypothesis we have examined the effect of cimetidine, an $\mathrm{H}_{2}$-blocking agent, on pentagastrin induced acid secretion and histamine production. If pentagastrin acts directly on the parietal cell, and histamine release is a passive phenomenon associated with gastric secretion, then $\mathrm{H}_{2}$ blockade should reduce both acid and histamine secretion. Alternatively, if histamine secretion is actually stimulated by pentagastrin then $\mathrm{H}_{2}$ blockade of the parietal cell should not affect the secretion of histamine induced by pentagastrin infusion, but only gastric acid secretion. The effect of cimetidine on pentagastrin induced gastric acid secretion and histamine production should therefore enable a distinction to be made between these two mechanisms.

\section{Methods}

SUBJECTS

Patients with duodenal ulcer diseases were allocated randomly into two groups. Group A was eight patients who received a two hour pentagastrin infusion test $(6 \mu \mathrm{g} / \mathrm{kg} / \mathrm{h})$ after fasting overnight. 
Group B was 16 patients who, in addition to the two hour pentagastrin infusion, also received cimetidine $200 \mathrm{mg}$ intravenously after one hour of pentagastrin. Gastric aspirate was collected in 10 minute fractions for measurement of acid and histamine. Venous blood samples were taken from a brachial vein at 10 minute intervals for histamine assay.

Eight healthy volunteers and two patients after total gastrectomy were given cimetidine $200 \mathrm{mg}$ intravenously after overnight fasting. Blood samples were taken at 10 minute intervals for histamine assay.

Acid and histamine were assayed by procedures published in detail previously. ${ }^{4}$ Briefly, gastric acid was measured by titration to $\mathrm{pH} \mathrm{7.0}$ using an automatic titrimeter (Copenhagen). Gastric histamine was assayed fluorometrically after extraction and purification procedures as outlined previously. ${ }^{4}$ Plasma histamine was assayed by an enzymatic-isotopic method. ${ }^{4}$

The gastric acid and histamine output were corrected for gastroduodenal loss by use of an inert non-absorbable marker (phenol red) to perfuse the stomach of the patient, and duodenogastric reflux by measurement of sodium ions in the gastric aspirate. ${ }^{5}$ The mean difference between the corrected and uncorrected values was $5.9 \pm 6.6 \%$.

Statistical comparisons were made using the Wilcoxon's matched-pairs signed-rank test. P values $<0.05$ are recorded as statistically significant. The effects of pentagastrin on acid and histamine production were compared with basal values. After cimetidine blockade, further statistical comparisons were made between values obtained after cimetidine and the values of the sample fraction immediately before cimetidine injection.

\section{Results}

\section{EFFECT OF PENTAGASTRIN ON ACID AND HISTAMINE OUTPUT}

Measurements of acid and histamine, in gastric aspirate and blood plasma, are listed in Table 1 and Table 2 for Group A and Group B patients respectively.

In Group A patients, gastric acid concentration increased from basal levels, median $31 \mathrm{mmol} / \mathrm{l}$, to peak levels, median $121 \mathrm{mmol} / \mathrm{l}(\mathrm{p}<0 \cdot 001)$, and cutput rose from basal median $0.5 \mathrm{mmol}$ to peak median $6.3 \mathrm{mmol}(\mathrm{p}<0.001)$ in the 10 minute fractions. Gastric histamine concentration fell from basal median $27 \cdot 7 \mathrm{nmol} / 1$ to $15.6 \mathrm{nmol} / \mathrm{l}(\mathrm{p}<0 \cdot 01)$ before returning to basal values after 90 minutes pentagastrin. Histamine output, however, rose from basal median $0.52 \mathrm{nmol}$ to $1.32 \mathrm{nmol}(\mathrm{p}<0.01)$ because of the rising volume of gastric secretion. Plasma histamine also rose from basal median 3.43 $\mathrm{nmol} / \mathrm{l}$ to a peak median $5 \cdot 19 \mathrm{nmol} / \mathrm{l} \quad(\mathrm{p}<0 \cdot 05)$ before falling back to basal levels after one hour of pentagastrin infusion.

For Group B patients, during the first hour of pentagastrin infusion, comparable changes in acid and histamine were measured. Acid concentration increased from basal 42 to $123 \mathrm{mmol} / \mathrm{l}(\mathrm{p}<0.001)$; output from 0.8 to $8.5 \mathrm{mmol}(\mathrm{p}<0.001)$. Gastric histamine concentration fell from basal 29.8 to 14.0 $\mathrm{nmol} / \mathrm{l}(\mathrm{p}<0.01)$, but output rose from 0.79 to 1.37 nmol $(\mathrm{p}<0 \cdot 01)$. Plasma histamine also rose from

Table 1 Acid and histamine during pentagastrin infusion test; Group A patients $(n=8)$

\begin{tabular}{|c|c|c|c|c|c|c|c|c|c|c|}
\hline \multirow{3}{*}{$\begin{array}{l}\text { Gastric } \\
\text { fraction } \\
(\text { no })\end{array}$} & \multicolumn{6}{|c|}{ Concentration } & \multicolumn{4}{|l|}{ Output } \\
\hline & \multicolumn{2}{|c|}{$\begin{array}{l}\text { Gastric acid } \\
(\mathrm{mmol} / \mathrm{l})\end{array}$} & \multicolumn{2}{|c|}{$\begin{array}{l}\text { Gastric histamine } \\
\text { (nmol/l) }\end{array}$} & \multicolumn{2}{|c|}{$\begin{array}{l}\text { Plasma histamine } \\
\text { (nmol/l) }\end{array}$} & \multicolumn{2}{|c|}{$\begin{array}{l}\text { Gastric acid } \\
\text { (mmol) }\end{array}$} & \multicolumn{2}{|c|}{$\begin{array}{l}\text { Gastric histamine } \\
\text { (nmol) }\end{array}$} \\
\hline & Median & Range & Median & Range & Median & Range & Median & Range & Median & Range \\
\hline 2 & 26 & $0-86$ & $58 \cdot 1$ & $13 \cdot 7-89 \cdot 9$ & $2 \cdot 02$ & $0.31-2 \cdot 82$ & 0.4 & $0 \cdot 0-() \cdot 7$ & 0.52 & $0 \cdot 16-0.94$ \\
\hline 3 & 31 & $0-75$ & $27 \cdot 7$ & $14.4-89.9$ & $3 \cdot 43$ & $1 \cdot 42-6 \cdot 30$ & 0.5 & $0 \cdot 0-2 \cdot 8$ & 0.49 & $0 \cdot 16-1.89$ \\
\hline 4 & 38 & $16-78$ & 51.9 & $12 \cdot 9-120 \cdot 7$ & $5 \cdot 06$ & $2 \cdot 66-5 \cdot 84$ & 0.7 & $(0 \cdot 2-3 \cdot()$ & $1 \cdot 13$ & $0.23-2 \cdot 17$ \\
\hline 5 & $81^{*}$ & $19-106$ & $23 \cdot 9$ & $13.4-103.8$ & $5 \cdot 09^{*}$ & $3 \cdot 63-6 \cdot 35$ & $3 \cdot 2$ & $0 \cdot 2-8 \cdot 0$ & $1 \cdot 18^{*}$ & $0 \cdot 20-2 \cdot 80$ \\
\hline 6 & $98^{*}$ & $41-124$ & $16 \cdot 3$ & $11 \cdot 7-82 \cdot 0$ & $5 \cdot 11^{*}$ & $2 \cdot 82-14 \cdot 07$ & $4 \cdot 2$ & $1 \cdot(-6.9$ & 0.70 & $0.31-3.28$ \\
\hline 7 & $114^{*}$ & 4()$-141$ & $15 \cdot 7$ & $8 \cdot 1-44 \cdot 0$ & $4 \cdot 47^{*}$ & $1 \cdot 87-10 \cdot 00$ & $5 \cdot 2$ & $1 \cdot 2-7 \cdot 8$ & $\left(0.84^{*}\right.$ & $0 \cdot 23-2 \cdot 13$ \\
\hline 8 & $107 *$ & $57-133$ & $20 \cdot 1$ & $7 \cdot 3-99 \cdot 0$ & $5 \cdot 19^{*}$ & $3 \cdot 19-9 \cdot 23$ & $6 \cdot 3$ & $1 \cdot 6-9 \cdot 6$ & $1 \cdot 19^{*}$ & $0 \cdot 17-5 \cdot 74$ \\
\hline 9 & $118^{*}$ & $57-129$ & $15 \cdot 6$ & $7 \cdot 6-42 \cdot 3$ & $4 \cdot 36$ & $3 \cdot 62-9 \cdot 40$ & $5 \cdot 8$ & $1 \cdot 7-13 \cdot 1$ & $0.86^{*}$ & $0.60-1.90$ \\
\hline 10 & $116^{*}$ & $59-137$ & $15 \cdot 7$ & $7 \cdot 6-31 \cdot 7$ & $4 \cdot 64$ & $3 \cdot 07-6 \cdot 29$ & $5 \cdot 8$ & $1 \cdot 7-7 \cdot 9$ & 0.86 & $(0 \cdot 17-1 \cdot 10$ \\
\hline 11 & $114^{*}$ & $64-141$ & $15 \cdot 7$ & $6 \cdot 5-49 \cdot 8$ & $4 \cdot 50$ & $1.49-7.98$ & $5 \cdot 6$ & $1 \cdot 6-8 \cdot 8$ & 0.79 & $0 \cdot 15-2 \cdot 15$ \\
\hline 12 & $121^{*}$ & $45-141$ & $17 \cdot 4$ & $2 \cdot 2-41 \cdot 1$ & $3 \cdot 43$ & $0 \cdot 22-4 \cdot 55$ & $6 \cdot 1$ & $1 \cdot 4-8 \cdot 7$ & $(0.85$ & $0 \cdot 33-2 \cdot 10$ \\
\hline 13 & $102^{*}$ & $52-136$ & $25 \cdot 1$ & $16 \cdot 7-47 \cdot 9$ & $3 \cdot 41$ & $1 \cdot 44-5 \cdot 23$ & $4 \cdot 3$ & $1 \cdot 7-10 \cdot 6$ & $0.94^{*}$ & $0.64-2.67$ \\
\hline 14 & $85^{*}$ & $43-139$ & $27 \cdot()$ & $16 \cdot 7-37 \cdot 7$ & $5 \cdot 35$ & $1 \cdot 22-7 \cdot 48$ & $5 \cdot 4$ & $1 \cdot 5-6 \cdot 3$ & $1 \cdot 12^{*}$ & $0.66-1.54$ \\
\hline 15 & $92^{*}$ & $17-135$ & $37 \cdot 7$ & $20 \cdot(-76 \cdot 9$ & $3 \cdot 07$ & $0.66-5.96$ & $4 \cdot 1$ & $0.7-6.9$ & $1 \cdot 32^{*}$ & $0 \cdot 66-3 \cdot 31$ \\
\hline
\end{tabular}

\footnotetext{
${ }^{*}$ Higher than fraction (2) and (3); $\mathrm{p}<0 \cdot(05$ : Wilcoxon's signed-rank test
} 
Table 2 Acid and histamine during pentagastrin and cimetidine; Group B patients $(n=16)$

\begin{tabular}{|c|c|c|c|c|c|c|c|c|c|c|}
\hline \multirow{3}{*}{$\begin{array}{l}\text { Gastric } \\
\text { fraction } \\
\text { (no) }\end{array}$} & \multicolumn{6}{|c|}{ Concentration } & \multicolumn{4}{|l|}{ Output } \\
\hline & \multicolumn{2}{|c|}{$\begin{array}{l}\text { Gastric acid } \\
(\mathrm{mmol} / \mathrm{l})\end{array}$} & \multicolumn{2}{|c|}{$\begin{array}{l}\text { Gastric histamine } \\
\text { (nmol/l) }\end{array}$} & \multicolumn{2}{|c|}{$\begin{array}{l}\text { Plasma histamine } \\
\text { (nmol/l) }\end{array}$} & \multicolumn{2}{|c|}{$\begin{array}{l}\text { Gastric acid } \\
\text { (mmol) }\end{array}$} & \multicolumn{2}{|c|}{$\begin{array}{l}\text { Gastric histamine } \\
\text { (nmol) }\end{array}$} \\
\hline & Median & Range & Median & Range & Median & Range & Median & Range & Median & Range \\
\hline 2 & 35 & $0-80$ & $28 \cdot 6$ & $11 \cdot 4-98 \cdot 1$ & $3 \cdot 52$ & $1 \cdot 65-8 \cdot 20$ & $1 \cdot 0$ & $0 \cdot 0-2 \cdot 6$ & 0.75 & $0.24-1.91$ \\
\hline 3 & 42 & $0-97$ & $29 \cdot 8$ & $9 \cdot 1-110 \cdot 6$ & $3 \cdot 56$ & $0.79-7.96$ & 0.8 & $0 \cdot(1)-2 \cdot 6$ & 0.79 & $0.11-1.88$ \\
\hline 4 & 45 & $0-125$ & $28 \cdot 3$ & $11 \cdot 4-100 \cdot 6$ & $6 \cdot 47^{*}$ & $3 \cdot 14-15 \cdot 17$ & $1 \cdot 1$ & $0 \cdot(-9 \cdot 2$ & $0 \cdot 86^{*}$ & $0 \cdot 26-5 \cdot 44$ \\
\hline 5 & $90^{*}$ & $35-129$ & $21 \cdot 0$ & $7 \cdot 5-63 \cdot 2$ & $5 \cdot 17^{*}$ & $3.05-14.76$ & $4 \cdot 1$ & $0.8-9.9$ & $1 \cdot 20^{*}$ & $0.34-3.96$ \\
\hline 6 & $112^{*}$ & $47-139$ & $14 \cdot 0$ & $7 \cdot 5-33 \cdot 3$ & 5.97 & $2 \cdot 14-12 \cdot 70$ & $6 \cdot 6$ & $2 \cdot 1-13 \cdot 9$ & $1 \cdot 13^{*}$ & $0.46-5.75$ \\
\hline 7 & $123^{*}$ & $70-131$ & $16 \cdot 3$ & $5 \cdot()-45 \cdot 1$ & $4 \cdot 06$ & $1 \cdot 52-16 \cdot 10$ & $8 \cdot 4$ & $3 \cdot 2-15 \cdot 9$ & $1 \cdot 37^{*}$ & $0.28-4 \cdot 65$ \\
\hline 8 & $123^{*}$ & $77-145$ & $18 \cdot 7$ & $4 \cdot 1-45 \cdot 1$ & $5 \cdot 69^{*}$ & $1 \cdot 03-16 \cdot 08$ & $6 \cdot 7$ & $2 \cdot 5-13 \cdot 9$ & $1 \cdot 17^{*}$ & $0 \cdot 23-4 \cdot 11$ \\
\hline 9 & $112^{*}$ & $66-134$ & $15 \cdot 4$ & $3 \cdot 2-32 \cdot 1$ & $5 \cdot 23$ & $1.66-10.59$ & $6 \cdot 6$ & $2 \cdot 9-13 \cdot 7$ & $1 \cdot 31^{*}$ & $(0.14-2.59$ \\
\hline 10) & $100)^{*}$ & $25--140$ & $22 \cdot()$ & $4 \cdot 6-176 \cdot 8$ & $6 \cdot 51^{*}$ & $2 \cdot 05-17 \cdot 85$ & $4 \cdot 4$ & $0 \cdot 6-10 \cdot 8$ & $1.27^{*}$ & $0.39-3.59$ \\
\hline 11 & 61 & $0-109$ & $53 \cdot 2^{*}$ & $5 \cdot 9-176 \cdot 1$ & $12 \cdot 43^{*}$ & $4 \cdot 67-29 \cdot 86$ & $1 \cdot 0$ & $0 \cdot()-4 \cdot 7$ & $1 \cdot 17^{*}$ & $0 \cdot 39-4 \cdot 31$ \\
\hline 12 & 61 & $2-118$ & $39 \cdot()$ & $23 \cdot 9-144 \cdot 7$ & $7 \cdot 15^{*}$ & $3 \cdot 18-21 \cdot 17$ & $1 \cdot 2$ & $0 \cdot()-5 \cdot 5$ & $1 \cdot 11^{*}$ & $0.20-3.27$ \\
\hline 13 & 64 & $7-124$ & $35 \cdot()$ & $5 \cdot(1)-89 \cdot 7$ & $6.75^{*}$ & $1.75-14.47$ & $1 \cdot 8$ & $0.5-6 \cdot 1$ & $1 \cdot 01^{*}$ & $0 \cdot 20-2.93$ \\
\hline 14 & 62 & $0-124$ & 28.9 & $1.5-118.6$ & $6 \cdot 37^{*}$ & $1 \cdot 56-13 \cdot 51$ & 1.9 & $0.1-4.9$ & $0.94^{*}$ & $0.07-3.46$ \\
\hline 15 & 65 & $16-125$ & $45 \cdot 7^{*}$ & $14 \cdot()-223 \cdot 6$ & $6 \cdot 87^{*}$ & $3 \cdot 40-15 \cdot 80$ & 1.8 & $0 \cdot(1)-5 \cdot 6$ & $1 \cdot 08^{*}$ & $0.42-7.00)$ \\
\hline
\end{tabular}

* Higher than fraction (2) and (3): $\mathrm{p}<0.05$; Wilcoxon `s signed-rank test

basal 3.56 to peak $6.47 \mathrm{nmol} / 1(\mathrm{p}<0 \cdot() 1)$.

The output of histamine as assayed in the gastric aspirate closely paralleled that of acid. The total summation of histamine in the aspirate during the first hour of pentagastrin infusion, in both Group A and Group B, was related to the total acid secreted. A similar correlation was observed during the second hour of pentagastrin infusion in Group $\mathrm{A}$ patients (Fig. 1).

\section{EFFECT OF CIMETIDINE ON PENTAGASTRIN} INDUCED ACID AND HISTAMINE

Cimetidine, $200 \mathrm{mg}$ intravenously, was given to

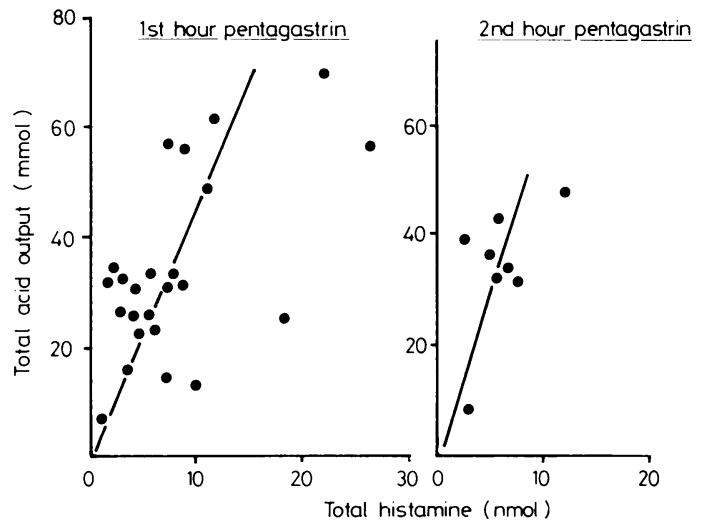

Fig. 1 Relationship between total acid and histamine output during pentagastrin infusion Left: Group $A$ and Group B: $n=24 ; r=0.58 ; p<0.01$ Right: Group A: $n=8 ; r=0.61 ; p<0.05$
Group B patients after one hour of pentagastrin infusion. Gastric acid secretion fell immediately (Table 2). Acid concentration fell from $112 \mathrm{mmol} / \mathrm{l}$ immediately before cimetidine to $61 \mathrm{mmol} / \mathrm{l}$ $(\mathrm{p}<0.001)$; output dropped from 6.6 to $1.0 \mathrm{mmol}$ in the 10 minute fraction. Gastric histamine concentration, however, rose from 15.4 to 53.2 $\mathrm{nmol} / \mathrm{l}(\mathrm{p}<0.01)$, which is also higher than the basal value of $29.8 \mathrm{nmol} / \mathrm{l}(\mathrm{p}<0 \cdot 01)$ as the gastric secretion volume declined. In contrast with the concentration data, histamine output in all 10 minute fractions were not significantly different from that before cimetidine, though they were higher than the basal median $0.79 \mathrm{nmol}(\mathrm{p}<0.01)$. Plasma histamine rose from 5.23 to $12.43 \mathrm{nmol} / \mathrm{l}(\mathrm{p}<0.01)$ and remained high throughout the subsequent period of pentagastrin infusion.

Figure 2 illustrates the summation of histamine and acid output in gastric juice collected during the basal period, the first hour of pentagastrin and the second hour of pentagastrin infusion in Group A and Group B patients. The latter group also received cimetidine at the end of the first hour pentagastrin. In Group A, gastric histamine rose from basal median $3.75 \mathrm{nmol} / \mathrm{h}$ to $5.85 \mathrm{nmol} / \mathrm{h}$ $(p<0.01)$ in the first hour pentagastrin and to 5.89 $\mathrm{nmol} / \mathrm{h}(\mathrm{p}<0 \cdot 01)$ in the second hour of pentagastrin. Gastric acid rose from 3.6 to $25.9(p<0.001)$ and then to $32.3 \mathrm{mmol} / \mathrm{h} \quad(\mathrm{p}<0 \cdot 001)$. In Group $B$ patients, histamine output rose from basal median 4.39 to $7.31 \mathrm{nmol} / \mathrm{h}(\mathrm{p}<0 \cdot 001)$ in the first hour of pentagastrin. With cimetidine blockade, histamine output in the second hour pentagastrin remained unchanged, media $6.87 \mathrm{nmol} / \mathrm{h}$, which is higher than 


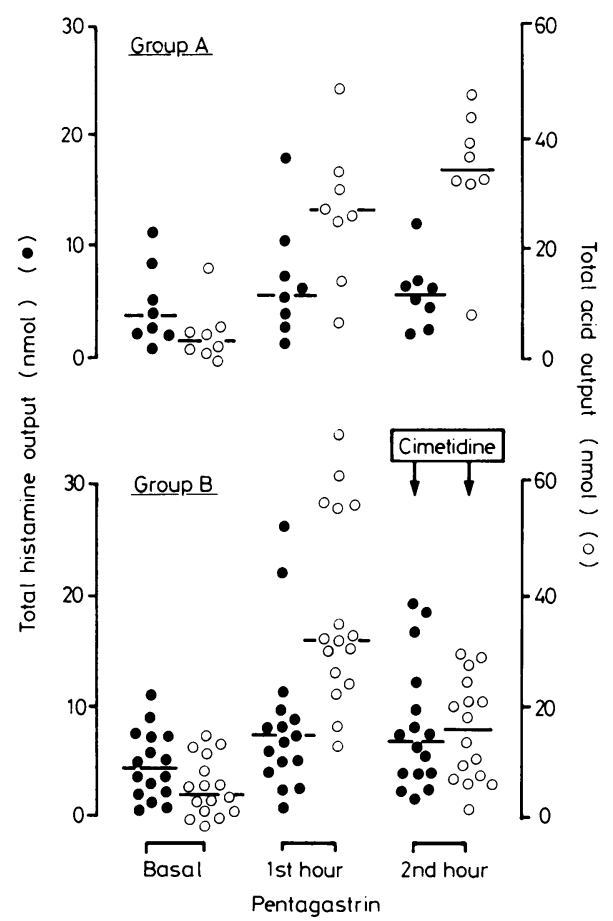

Fig. 2 Total histamine and acid output during basal, first hour and second hour pentagastrin infusion

Upper: Group $A: n=8$

Lower: Group B: $n=16$, cimetidine, $200 \mathrm{mg}$ intravenous

bolus, before second hour of pentagastrin infusion

basal $(p<0.001)$ but not significantly different from that of the first hour pentagastrin in either Group A or Group B, nor from that of the second hour pentagastrin in group A. Gastric acid rose from basal median 5 to $32 \cdot 1 \mathrm{mmol} / \mathrm{h}$ in the first hour of pentagastrin infusion but fell to $16 \cdot 2 \mathrm{mmol} / \mathrm{h}$ in the second hour of pentagastrin after cimetidine blockade. Thus, cimetidine reduced acid but not histamine in the gastric secretion.

3 EFFECT OF CIMETIDINE ON PLASMA HISTAMINE IN HEALTHY VOLUNTEERS AND PATIENTS WITH TOTAL GASTRECTOMY

Figure 3 shows the effect of cimetidine $200 \mathrm{mg}$ intravenously, on plasma histamine concentration in healthy subjects. There was a peak between 10 and 20 minutes after cimetidine followed by a rapid fall to basal levels. Similar changes were observed in patients after total gastrectomy (Fig. 4). Thus, cimetidine induces histamine release into the circulatory systems from sources other than the stomach.

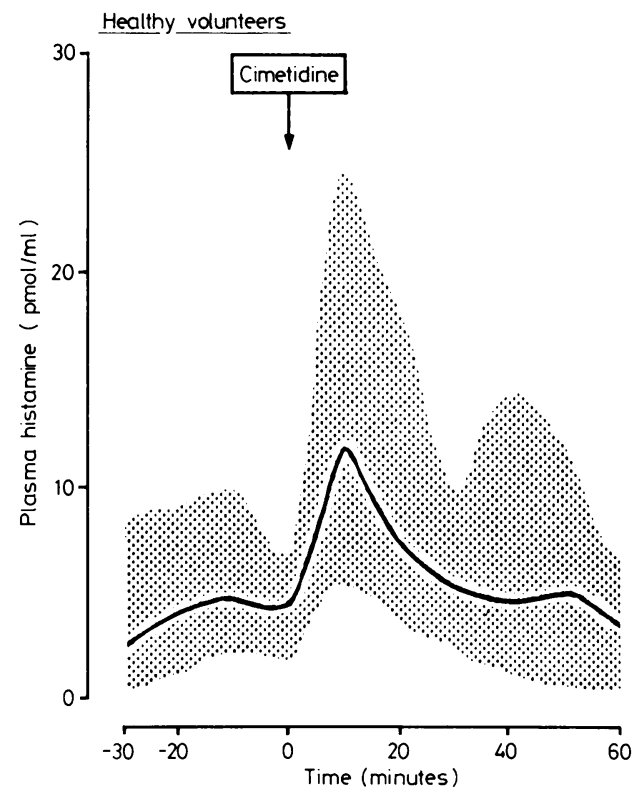

Fig. 3 Changes in plasma histamine in eight healthy volunteers after cimetidine, $200 \mathrm{mg}$ intravenous bolus Line: median; shaded area: range

* Significantly higher than basal $(p<0.05)$

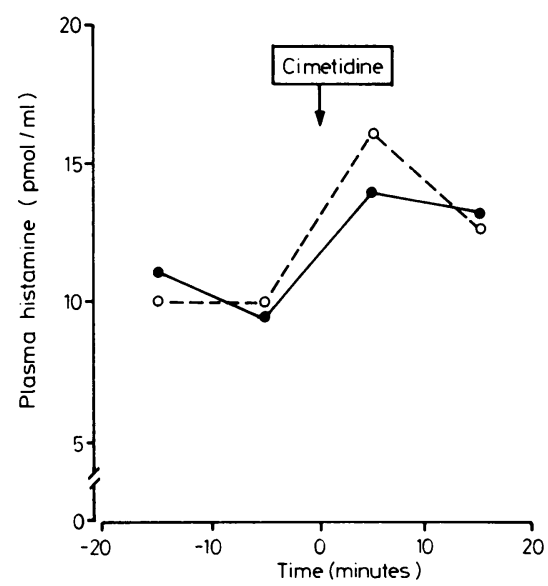

Fig. 4 Changes in plasma histamine in two patients after total gastrectomy after cimetidine $200 \mathrm{mg}$ intravenous bolus 


\section{Discussion}

Histamine is the most potent substance stimulating gastric acid secretion. It is widely distributed throughout the body and is present in abundance in the fundus of the stomach. During gastric acid secretion histamine appears in gastric juice. It is apparent that histamine is highly likely to have a role in the physiological control of gastric acid secretion. Many questions and uncertainties persist, however, as to the precise mechanism, if any, by which histamine has its action.

Many other secretagogues, including gastrin and its synthetic analogue, pentagastrin, can act on the gastric mucosa. One explanation of the phenomenon might be that histamine acts as a final common pathway for gastric acid release. In mammals $\mathrm{H}_{2}$ receptor antagonists inhibit the secretory action of histamine, pentagastrin, 2-deoxyglucose and insulin. The secretory response of kitten fundic mucosa to acetylcholine, however, is not blocked by metiamide, ${ }^{6}$ and the cholinergic antagonist atropine inhibits pentagastrin induced secretion in dogs. ${ }^{2}$

These observations are difficult to fit into a theory which proposes a single final common transmitter. An alternative to pharmacological studies is to examine the effect of secretagogues on isolated cells. ${ }^{3}$ The responses, however, measured in such experiments are small and may not correspond to the physiological condition. These lines of evidence do not therefore allow a conclusion on the roles of gastrin and histamine in acid secretion.

It is now possible to assay histamine in biological fluids and tissues with great sensitivity and precision. Such measurements of changes in histamine during secretion may offer a better method of determining the role of histamine.

The fluorometric method developed by Lorenz ${ }^{7}$ is suited to the assay of gastric histamine, being fast and economical. Specimens with very low concentration, such as plasma, are more conveniently assayed by the method of Schaff and Beaven. ${ }^{8}$ The latter technique is more expensive and time consuming than fluorometric assay and the methods are therefore complementary. The precision and accuracy for both methods of histamine assay have been previously described. ${ }^{4}$

We have previously reported that the pattern of histamine and acid release during pentagastrin infusion is so close as to suggest a functional relationship. ${ }^{4}$ Pentagastrin induced an increase in histamine output in gastric juice. In the present study histamine rose from basal median 3.75 to 5.85 $\mathrm{nmol} / \mathrm{h}$, and from basal 4.39 to $7.31 \mathrm{nmol} / \mathrm{h}$ in the first hour of pentagastrin for the two groups of patients respectively. The stimulated values are of similar magnitude to those reported by Parkin et al, ${ }^{9}$ but 10 -fold less than those reported by Peden et al. ${ }^{10}$ The discrepancy may be owing to different methodologies, as Parkin's group and ours are using similar assay procedures.

After cimetidine blockade, gastric acid fell rapidly but histamine output in gastric juice did not change. The evidence of the effect of cimetidine on gastric acid secretion presented here suggests that histamine release after pentagastrin infusion is independent of gastric acid secretion, and not a passive 'washout' phenomenon. Similar findings have been reported by Peden et al. ${ }^{10}$

Cimetidine affects the enzymatic isotopic assay of histamine. It interferes with the assay as it increases the blank value in the standard curve and inhibits the enzymatic reaction at high concentrations (Fig. 5). At concentrations below $2 \mu \mathrm{g} /$ incubation, however, the interference from cimetidine is not significant. The concentration of cimetidine in the blood of healthy human subjects after intravenous bolus injection falls rapidly at first and then at a slower rate. ${ }^{5}$ After an intravenous bolus injection of $100 \mathrm{mg}$ cimetidine, the concentrations of cimetidine in the blood at 5 minutes and 10 minutes were $4 \cdot 7$ and $3 \mu \mathrm{g} / \mathrm{ml}$ respectively. ${ }^{5}$ As only $0.1 \mathrm{ml}$ plasma was used in the assay, the estimated concentration of cimetidine in the plasma samples in the present series of experiments should be below $2 \mu \mathrm{g} /$ incubation, and would not be expected to interfere with the histamine assay.

The release of histamine into plasma parallels gastric secretion. The pattern of histamine release

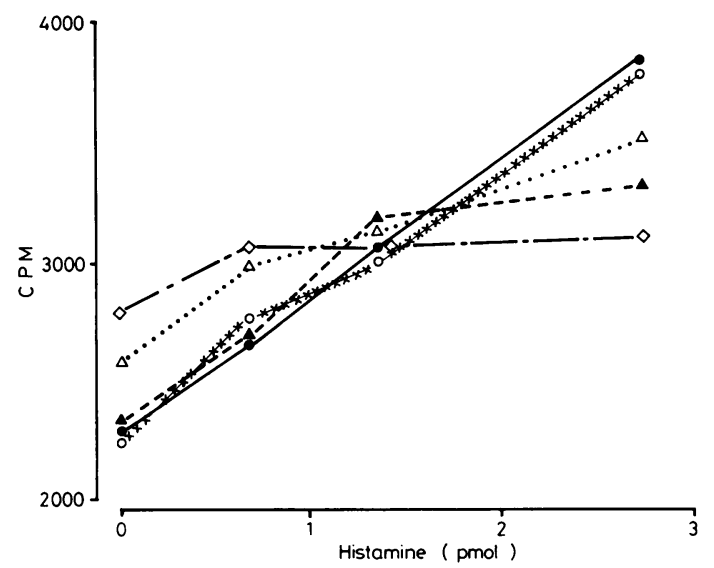

Fig. 5 Interference from cimetidine with the standard curves obtained by single isotope assay of histamine

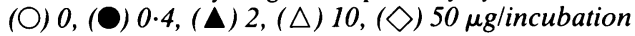


into the plasma is complicated by the effect of cimetidine on other tissue histamine stores. Cimetidine when given alone induces a transient rise in histamine level in blood plasma. Other investigations reported an immediate rise and then fall to basal value in 10 minutes after cimetidine. ${ }^{12}$ In the present study, the plasma histamine level returned to basal in 20 minutes after cimetidine (Fig. 3). Together with pentagastrin, however, a significant rise in plasma histamine level is sustained (Table 2). It is clear from our data that plasma histamine remains raised after cimetidine injection and its associated peak of histamine release, indicating sustained secretion during pentagastrin infusion despite cimetidine blockade.

These data are compatible with the hypothesis that pentagastrin acts indirectly, by releasing histamine in the gastric mucosa. The results confirm that cimetidine has no action by inhibiting histamine release. The observation is interesting in the light of the finding that mucosal histamine concentration increases during cimetidine treatment of duodenal ulceration. ${ }^{13}$ Further experiments are in progress to study the effects of short and long term cimetidine blockade on gastric mucosal histamine and the activity of histamine methyltransferase.

These results show such a potent release of gastric histamine during pentagastrin infusion as to be compatible with a physiological pathway. Although our results cannot exclude the possibility that increase in histamine release is a non-specific effect consequent to onset of secretion, ${ }^{10}$ the association of histamine and gastric acid release found in our previous $^{4}$ and present studies was so close that a functional relationship seems likely. Our results are compatible with the theory that pentagastrin acts indirectly on the parietal cell by causing histamine release. A further pathway, in which gastrin acts on the parietal cell by a receptor blocked by $\mathrm{H}_{2-}$ antagonists, cannot be excluded by our present data. If such a route exists its physiological significance as compared with the histamine releasing route may be small, in view of the large volume of histamine secretion induced at very low pentagastrin concentrations.

We conclude that histamine release during pentagastrin infusion is a major stimulus to gastric acid secretion.

We should like to thank the Mason Medical Research Foundation and the Wellcome Foundation for their support of this project, $\mathrm{Mr} \mathrm{S} \mathrm{K} \mathrm{Li} \mathrm{and} \mathrm{Miss}$ A Brown for technical assistance and Mrs Iris Fisher for typing the manuscript.

\section{References}

1 Code CF. Histamine and gastric secretion; a later look, 1955-1965. Fed Proc 1965; 24: 1311-21.

2 Grossman MI, Konturek SJ. Inhibition of acid secretion in dog by metiamide, a histamine antagonist acting on $\mathrm{H}_{2}$ receptors. Gastroenterology 1974; 66: 517-21.

3 Soll A. The interaction of histamine with gastrin and carbamylcholine on oxygen uptake in isolated mammalian parietal cells. J Clin Invest 1978; 61: 381-9.

4 Man WK, Saunders JH, Ingoldby C, Spencer J. Effect of pentagastrin on histamine output from the stomach in patients with duodenal ulcer. Gut 1981; 22: 916-22.

5 Baron JH. In: Clinical tests of gastric secretion. London: Macmillan, 1978.

6 Tepperman BL, Schofield B, Tepperman FS. Effect of metiamide on acid secretion from isolated kitten fundic mucosa. Can J Physiol Pharmacol 1975; 53: 1141-6.

7 Lorenz W, Benesch H, Barth E et al. Fluorometric assay of histamine in tissues and body fluids. $S$ Anal Chem 1970; 252: 94-100.

8 Shaff RE, Beavan MA. Increased sensitivity of the enzymatic isotopic assay of histamine: measurement of histamine in plasma and serum. Anal Biochem 1979; 94: 425-30).

9 Parkin JV, Lorenz W. Barth $\mathrm{H}$ et al. Assay and identification of histamine in human gastric aspirate by a fluorometric-fluorenzymatic technique. Its application in patients with chronic duodenal ulcer. Agents Actions 1982; 12: 17.

10 Peden N, Boyd EJS, Callachan $\mathrm{H}$ et al. The effect of Impromidine and pentagastrin on gastric output of histamine, acid and pepsin in man. Hepato-gastroenterol 1982; 29: 30-34.

11 Griffiths R, Lee RM, Taylor DC. Kinetics of cimetidine in man and experimental animals. In: Cimetidine-proceedings of the second international symposium on histamine $\mathrm{H}_{2}$-receptor. AmsterdamOxford: Excerpta Medica, 1977.

12 Lorenz W, Doenicke A, Schoning B et al. Histamine release. $\mathrm{H}_{1}+\mathrm{H}_{2}$. Receptor antagonists for premedication in anaesthesia and surgery. A critical view based on randomised clinical trials with Haemaccel and various antiallergic drugs. Agents Actions 1980; 10: 114-24.

13 Man WK. Saunders JH, Ingoldby C, Spencer J. Effect of cimetidine on the amounts of histamine in the gastric mucosa of patients with gastric or duodenal ulcers. Gut 1981; 22: 923-6. 